\title{
KARAKTERISTIK ORGANOLEPTIK COOKIES AMPAS KELAPA DENGAN PENGGUNAAN VCO
}

\author{
Dina Putri Pratami*1, Erminawati ${ }^{2}$, Yunika Purwanti ${ }^{3}$ \\ ${ }_{1,2}$ Program Studi Ilmu dan Teknologi Pangan, Fakultas Pertanian, Universitas Jenderal Soedirman \\ ${ }^{3}$ Program Studi Ilmu dan Teknologi Pangan, Fakultas Sains dan Tenologi, Universitas Muhadi Setiabudi \\ Email: ${ }^{1}$ pratamidinaputri@yahoo.com, ${ }^{2}$ erminawati@gmail.com, ${ }^{3}$ yunika@umus.ac.id
}

\begin{abstract}
Abstrak
Masyarakat Indonesia mulai tergantung pada bahan pangan yang berbahan baku terigu. Bahan tersebut dapat melemahkan ketahanan pangan nasional. Guna mengatasi hal tersebut, maka perlu peningkatan swasembada pangan dengan memanfaatkan berbagai jenis komoditi lokal, seperti kelapa. Pemanfaatan ampas kelapa mulai berkembang dikarenakan nilai gizi yang dikandung cukup baik. Tepung ampas kelapa dapat digunakan sebagai pengganti tepung terigu. Metode penelitian menggunakan rancangan acak kelompok (RAK), dengan 2 faktor yaitu pertama, proporsi tepung ampas kelapa:pati jagung:tepung terigu $(A 1=60 \%: 20 \%: 20 \%, A 2$ $=55 \%: 15 \%: 30 \%, A 3=50 \%: 10 \%: 40 \%)$ dan kedua, penambahan VCO dan margarin $(\mathrm{K} 1$ $=70 \%$ margarin dari berat bahan, K2 $=80 \%$ Margarin dari berat bahan, $\mathrm{K} 3=70 \%$ VCO dari berat bahan, $K 4=80 \%$ VCO dari berat bahan). Analisis yang dilakukan yaitu karakteristik organoleptik meliputi warna, aroma kelapa, rasa, tekstur, dan kesukaan). Hasil penelitian semakin menurunnya kandungan tepung ampas kelapa maka akan mempengaruhi mempengaruhi sensori cookies yang dihasilkan. Semakin meningkatnya kandungan VCO yang diberikan maka akan meningkatkan aroma dan tekstur namun menurunkan warna, rasa dan kesukaaan terhadap cookies.
\end{abstract}

Kata kunci-tepung ampas kelapa, vco, cookies

\section{PENDAHULUAN}

Kondisi masyarakat Indonesia yang tergantung pada bahan pangan yang berbahan baku terigu dapat melemahkan ketahanan pangan nasional. Guna mengatasi hal tersebut, maka perlu peningkatan swasembada pangan dengan memanfaatkan berbagai jenis komoditi lokal yang banyak dihasilkan di Indonesia. Tanaman kelapa merupakan tanaman serbaguna atau tanaman yang mempunyai nilai ekonomi yang tinggi. Seluruh bagian pohon kelapa dapat dimanfaatkan untuk kepentingan manusia, sehingga pohon ini sering disebut (tree of life) karena hampir seluruh bagian dari pohon, akar, daun dan buahnya dapat dipergunakan untuk kebutuhan manusia seharihari [1].

Ampas kelapa yang diperoleh pada umumnya dibuang begitu saja atau dijadikan pakan ternak. Kandungan nutrisi seperti serat kasar, karbohidrat dan protein yang terkandung pada ampas kelapa masih cukup tinggi dan dapat dikembangkan menjadi produk bernilai tambah lebih, salah satunya dalam bentuk cookies. Untuk meningkatkan kandungan nutrisi pada ampas kelapa dapat dilakukan modifikasi pada tepung ampas kelapa, hasil modifikasi dari tepung ampas kelapa ini dapat meningkatkan kandungan serat kasar, protein dan karbohidrat, dan dapat menurunkan kandungan lemak pada tepung ampas kelapa.

Peningkatan presentase margarin dan penambahan pati jagung membantu melembutkan dan mengompakkan adonan [2]. Penambahan pati jagung dapat membantu dalam pembentukan tekstur cookies dan meningkatkan kadar protein produk pangan tersebut. Pembentukan tekstur juga dapat dipengaruhi oleh emulsi yang digunakan, peggunaan VCO sebagai pengganti margarin dikarenkan sifat VCO yang seperti margarin yang dapat mempengaruhi pembentukan tekstur dan sensori cookies. Dengan memanfaatkan bahan baku lokal seperti tepung ampas kelapa, tepung jagung dan VCO pada pembuatan cookies dapat memanfaatkan limbah ampas kelapa sehingga

Submitted: Juni 2021, Accepted: Juli 2021, Published: Juli 2021

ISSN: 2775-247X (online), Website: http://jurnal.umus.ac.id/index.php/jtfp 
memberikan nilai tambah pada ampas kelapa. Pada penelitian ini hasil modifikasi tepung ampas kelapa yang terpilih akan diuji dengan diolah menjadi produk cookies.

Produk cookies dipilih karena merupakan produk bakery yang dapat diolah dari tepung non terigu dan tidak memerlukan tingkat pengembangan yang tinggi seperti halnya produk bakery lainnya. Cookies juga dapat dibuat dengan bahan serta alat yang sederhana, sehingga dalam implementasinya pembuatan produk ini dapat diaplikasikan pada masyarakat umum. Melalui pembuatan cookies dari tepung ampas kelapa termodifikasi ini diharapkan dapat dihasilkan makanan ringan yang mampu menjadi alternatif untuk mengurangi ketergantungan terhadap terigu namun memiliki karakteristik organoleptik yang dapat diterima.

\section{METODE PENELITIAN}

Bahan-bahan yang akan digunakan yaitu tepung terigu, tepung maezena (pati jagung), gula, telur, susu skim, VCO, margarin, Bahan-bahan untuk pembuatan tepung ampas kelapa terdiri dari kelapa parut yang diperoleh dari Pasar Wage Purwokerto, air, starter Mocaf bubuk "Starmof" yang diperoleh Lab. Mikrobiologi UPT BPPTK LIPI Bantul, Yogyakarta yang mana pada label Starmof ini tertulis mengandung 11 mikroba dengan total BAL $107 \mathrm{cfu} / \mathrm{g}$ (Lactobacillus plantarum G7 dan Pediococcus pentosaceus G5) dan total khamir $104 \mathrm{cfu} / \mathrm{g}$ (Saccharomyces cerevisiae Tr7). Peralatan yang dibutuhkan untuk pembuatan tepung ampas kelapa terdiri dari Cabinet dryer (Raja Pengering), gelas ukur (Pyrex Germany), ayakan 70 mesh (Han Jaya), grinder (Philips), timbangan analitik (AND GR-200), baskom dan timbangan. Peralatan untuk pembuatan cookies terdiri dari, baskom, mixer, Loyang, solet dan oven

Penelitian ini menggunakan metode eksperimental. Rancangan yang digunakan adalah Rancangan Acak kelompok (RAK) dengan tiga kali pengulangan.

Faktor yang diuji meliputi:

Proporsi tepung ampas kelapa, pati jagung terhadap tepung terigu (tepung ampas kelapa: pati jagung : tepung terigu). Faktor ini memiliki tiga taraf:

$\mathrm{A} 1=60 \%: 20 \%: 20 \%$

$\mathrm{A} 2=55 \%: 15 \%: 30 \%$

$\mathrm{A} 3=50 \%: 10 \%: 40 \%$

Konsentrasi penambahan VCO dan margarin ( berdasarkan berat total bahan) memiliki empat taraf:

$\mathrm{K} 1=70 \%$ margarin dari berat bahan

$\mathrm{K} 2=80 \%$ Margarin dari berat bahan

$\mathrm{K} 3=70 \%$ VCO dari berat bahan

$\mathrm{K} 4=80 \%$ VCO dari berat bahan

Dari dua faktor tersebut diperoleh 12 kombinasi perlakuan. Pengujian pada tahap ini dilakukan dalam 3 kali ulangan sehingga diperoleh unit percobaan berjumlah 36 unit. Pengujian variabel sensoris dilakukan terhadap sampel produk cookies. Uji sensoris ini dilakukan untuk menguji tingkat penerimaan terhadap produk cookies yang dihasilkan. Analisis organoleptik dilakukan terhadap rasa, warna, tekstur, aroma dan kesukaan terhadap produk cookies yang dihasilkan. Identifikasi sensori dilakukan dengan menggunakan uji afektif yang melibatkan 15 orang panelis semi terlatih yang merupakan mahasiswa Ilmu dan Teknologi Pangan UNSOED. Pengujian dilakukan terhadap 12 sampel cookies yang mewakili setiap perlakuan dengan menggunakan sistem penilaian hedonik dengan parameter sebagai berikut.

Tabel 1. Parameter penilaian uji organoleptik cookies

\begin{tabular}{cccccc}
\hline \multirow{2}{*}{ Skor } & \multicolumn{5}{c}{ Parameter } \\
\cline { 2 - 6 } & Warna & Aroma & Rasa & Tekstur & Kesukaan \\
\hline 1 & Coklat tua & Tidak harum & Tidak enak & Tidak remah & Tidak suka \\
2 & Coklat & Agak harum & Agak enak & Agak remah & Agak suka \\
3 & Coklat & Harum & Enak & Remah & Suka
\end{tabular}




\begin{tabular}{|c|c|c|c|c|c|}
\hline 4 & $\begin{array}{c}\text { Kuning } \\
\text { kecoklatan }\end{array}$ & Sangat harum & Sangat enak & Sangat remah & Sangat suka \\
\hline
\end{tabular}

\section{HASIL DAN PEMBAHASAN}

Hasil analisis ragam pengaruh perlakuan proporsi tepung ( A ), jenis emulsi ( K ), disajikan pada Tabel 2.

Tabel 2. Hasil analisis ragam pengaruh perlakuan proporsi tepung ( A ), jenis emuls ( $\mathrm{K}$ ) serta kombinasi perlakuan terhadap variabel sensori yang diamati

No Variable Perlakuan

A x K

\begin{tabular}{lll}
\hline 1 & warna & $*$ \\
2 & Aroma & $*$ \\
3 & Rasa & $*$ \\
4 & Tekstur & $*$ \\
5 & Kesukaan & $*$ \\
\hline
\end{tabular}

Keterangan : $\mathrm{A}=$ proporsi tepung, $\mathrm{K}=$ proporsi dan jenis emulsi, $\mathrm{AxK}=$ kombinasi antar proporsi tepung dengan proporsi dan jenis emulsi; tn $=$ tidak berpengaruh nyata, ${ }^{*}=$ berpengaruh nyata.

\subsection{Warna}

Warna pada produk pangan merupakan salah satu daya tarik masyarakat untuk mengkonsumsi suatu produk. Masyarakat cenderung menyukai warna makanan yang menarik, namun masih dalam batas wajar warna makanan pada umumnya. Pada Gambar 1 menunjukan kombinasi perlakuan terhadap variabel warna.

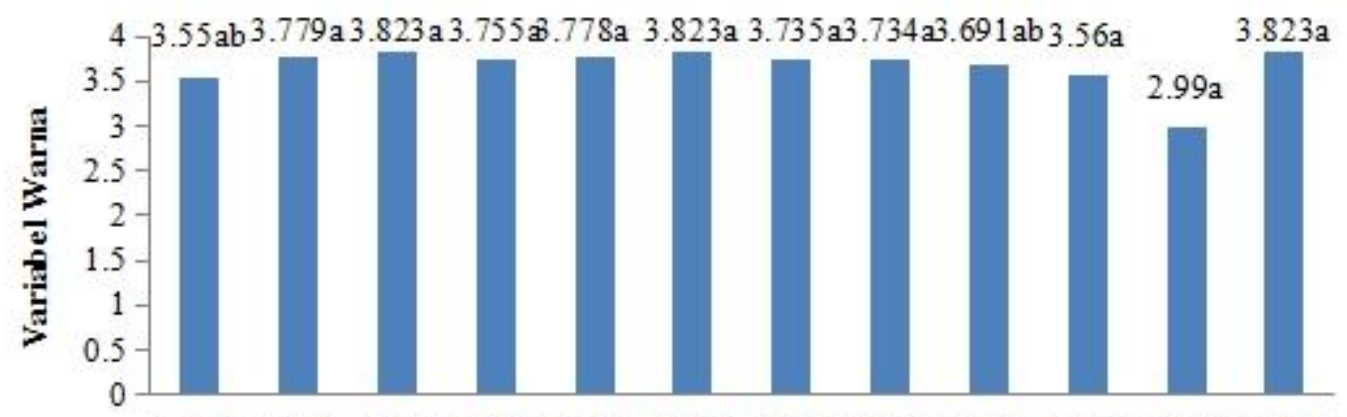

A1K1 A1K2 A1K3 A1K4 A2K1 A2K2 A2K3 A2K4 A3K1 A3K2 A3K3 A3K4

Kombinasi Perlakuan

Keterangan :

1. $\mathrm{A}=$ Proporsi tepung ampas kelapa : pati jagung : tepung terigu ( $\mathrm{A} 1: 60 \%: 20 \%: 20 \%$ , A2 : 55\%:15\%:30\%, A3 : 50\%: 10\%:40\% )

2. $\mathrm{K}=$ Proporsi dan jenis emulsi( $\mathrm{K} 1: 70 \%$ margarin, $\mathrm{K} 2: 80 \%$ margarin, $\mathrm{K} 3: 70 \%$ VCO, K4 : 80\% VCO ).

Gambar 1. Rata- rata variable warna cookies tepung ampas kelapa berdasarkan kombinasi perlakuan.

Gambar 1 menunjukan bahwa semakin menurunnya proporsi tepung ampas kelapa yang diberikan maka skor warna yang didapatkan meningkat, hal ini dikarenakan kandungan protein dan karbohidrat khususnya gula reduksi yang terkandung pada tepung yang akan menghasilkan reaksi Mailard, sedangkan pada penggunaan emulsi dan proporsi emulsi yang berbeda semakin meningkatnya margarin yang diberikan akan meningkatkan skor warna yang didapatkan, namun 
pada VCO skor warna yang dihasilkan lebih rendah dari pada margarin, hal ini dikarenakan adanya pengaruh warna pada masing-masing emulsi, warna margarin cenderung lebih kuning dibandingkan warna VCO, kandungan asam lemak yang berbeda dan adanya proses pemanggangan pada proses pembuatan cookies yang dapat mempengaruhi warna.

Warna biskuit meningkat dengan penambahan tepung kelapa yang dihilangkan lemaknya, yang berakibat pada pengurangan skor kualitas untuk warna biscuit [3]. Salah satu penentuan mutu suatu bahan pangan yang dapat dipertimbangkan adalah faktor warna [4]. Pengaruh suhu pemanggangan terhadap warna dari suatu bahan makanan disebabkan oleh adanya warna gelap yang timbul akibat reaksi pencoklatan non enzimatis atau reaksi Maillard. Reaksi antara gugus karbonil gula pereduksi dengan gugus amino protein disebut reaksi Maillard yang menghasilkan warna coklat pada bahan, yang dikehendaki atau malah menjadi pertanda penurunan mutu. Warna coklat pada penggorengan ubi jalar dan singkong, serta pencoklatan yang indah dari berbagai roti adalah warna yang dikehendaki.

\subsection{Aroma Kelapa}

Aroma merupakan salah satu faktor penentu kualitas produk makanan. Di industri pangan pengujian aroma di anggap penting karena dapat dengan cepat memberikan hasil penilaian terhadap produk tentang diterima atau tidaknya produk tersebut. Pada umumnya bau atau aroma yang diterima oleh hidung dan otak lebih banyak merupakan ramuan atau campuran empat bau utama yaitu harum, asam, tengik dan hangus [4]. Aroma yang diuji pada cookies adalah aroma khas kelapa. Ini dikarenakan jumlah proporsi tepung kelapa lebih banyak dibandingkan tepung terigu dan pati jagung.

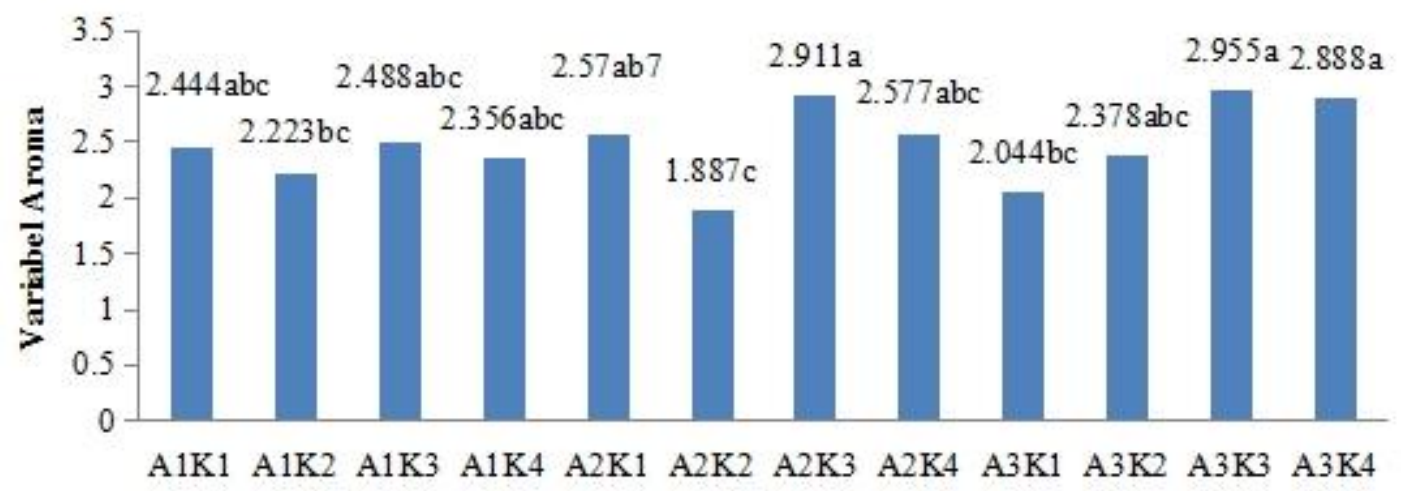

Kom binasi Perlakuan

Keterangan :

1. A = Proporsi tepung ampas kelapa : pati jagung : tepung terigu ( A1 : 60\%: 20\%:20\%, A2 : $55 \%: 15 \%: 30 \%$, A3 : 50\%: $10 \%: 40 \%$ )

2. $\mathrm{K}=$ Proporsi dan jenis emulsi( $\mathrm{K} 1: 70 \%$ margarin, $\mathrm{K} 2: 80 \%$ margarin, $\mathrm{K} 3: 70 \% \mathrm{VCO}$, $\mathrm{K} 4: 80 \% \mathrm{VCO}$ )

Gambar 2. Nilai rata-rata variable aroma, pada kombinasi perlakuan proporsi tepung dengan proporsi dan jenis emulsi.

Kombinasi perlakuan proporsi tepung dengan proporsi dan jenis emulsi, berpengaruh nyata pada aroma kelapa. Adanya kecenderungan menurun pada kombinasi perlakuan, hal ini di karenakan kandungan protein dan lemak yang terkandung pada tepung ampas kelapa maupun pada emulsi yang dapat bereaksi dan menghasilkan aroma pada cookies. Nilai rata-rata tertinggi didapatkan pada perlakuan A3K3 yaitu 2.95 dan rata-rata terendah pada A2K2 1.87, hasil tersebut sesuai dengan penelitian menyebutkan bahwa aroma cookies kontrol dan cookies tepung kelapa masing-masing adalah $7.5 \pm 1.35$ dan $8.4 \pm 0.84$. Penambahan tepung kelapa, gula kelapa dan VCO menyumbang aroma kelapa yang lebih kuat pada cookies tepung kelapa [5]. 
Sebuah studi serupa mengenai pengembangan kue bebas gluten berbasis kelapa juga menunjukkan nilai rata-rata tertinggi untuk aroma karena rasanya khas dari bubuk kelapa [6]. Hal ini dikarenakan kandungan lemak dan protein yang tinggi sehingga mendaptkan aroma kelapa dengan rata-rata nilai yang tinggi karena protein yang terkandung akan terdegradasi sedangkan lemak akan mengalami reaksi oksidasi, hal ini sesuai dengan teori yang disampaikan yang menyatakan bahwa timbulnya aroma atau bau dikarenakan adanya zat bau yang 14 bersifat volatil (mudah menguap) [7].

\subsection{Rasa}

Rasa dapat dipakai sebagai indikator kesegaran dan penyimpangan bahan pangan. Cita rasa makanan merupakan salah satu faktor penentu bahan makanan.

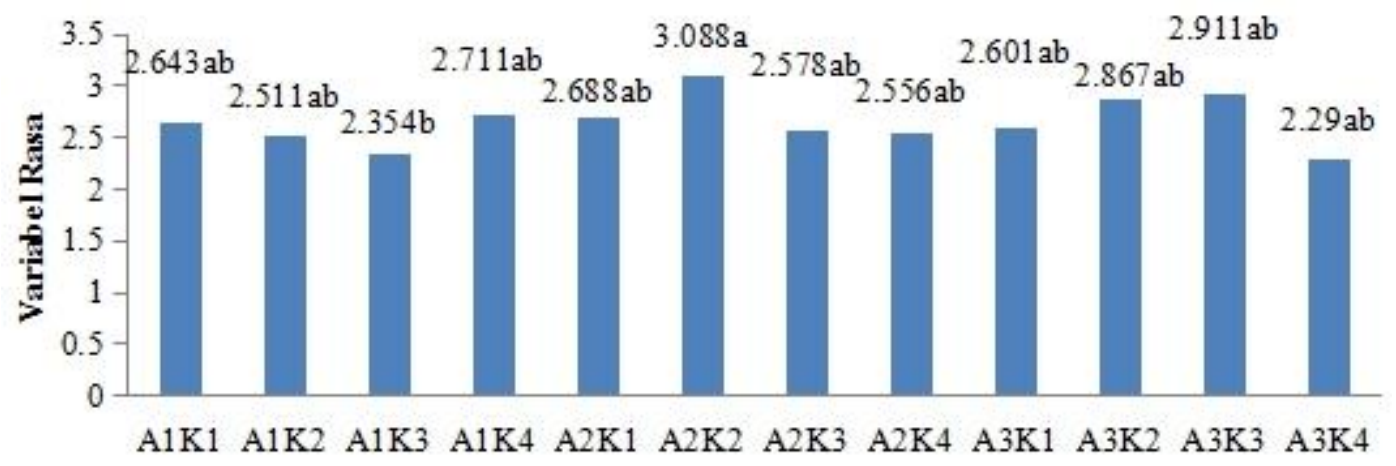

Kombinasi Perlakuan

Keterangan

1. $A=$ Proporsi tepung ampas kelapa : pati jagung : tepung terigu ( A1 : 60\%: 20\%:20\%, A2 : $55 \%: 15 \%: 30 \%, A 3: 50 \%: 10 \%: 40 \%$ )

2. $\mathrm{K}=$ Proporsi dan jenis emulsi( $\mathrm{K} 1: 70 \%$ margarin, $\mathrm{K} 2: 80 \%$ margarin, $\mathrm{K} 3: 70 \% \mathrm{VCO}$, $\mathrm{K} 4: 80 \% \mathrm{VCO}$ ).

Gambar 3. Nilai rata-rata variable rasa, pada kombinasi perlakuan proporsi tepung dengan proporsi dan jenis emulsi.

Hasil analisis ragam pada kombinasi perlakuan proporsi tepung dengan proporsi dan jenis emulsi, terlihat adanya perbedaan yang nyata dan adanya kecenderungan peningkatan dengan berkurangnya proporsi tepung ampas kelapa dan meningkatnya proporsi emulsi yang diberikan. Hal ini dikarenkan lemak yang terkandung pada emulsi memberikan rasa yang gurih pada cookies. Penurunan proporsi tepung ampas kelapa tidak memberikan pengaruh nyata terhadap rasa. Rasa gurih yang dihasilkan pada cookies didapatkan pada penambahan emulsi, hal ini sesuai dengan pernyataan substitusi 50 persen tepung kelapa yang dihilangkan lemaknya menurunkan skor untuk rasa dari 6,17 menjadi 4,80 [3].

Hasil rata-rata nilai tertinggi pada perlakuan $\mathrm{A} 2 \mathrm{~K} 23.08$ dan terendah pada pelakuan A1K3 2.35, hal ini dikarenakan adanya interaksi lemak dan protein yang terjadi pada cookies. Penyebab terjadinya peningkatan rasa gurih dari suatu produk ditentukan oleh besarnya kandungan protein dan lemak [4].

\subsection{Tekstur}

Tekstur merupakan gambaran dari atribut bahan makanan yang dihasilkan melalui kombinasi sifat-sifat fisik dan kimia, diterima secara luas oleh sentuhan, penglihatan dan pendengaran. Tekstur dari biskuit meliputi kerenyahan, kekerasan dan daya patah. Tekstur adalah sensasi tekanan yang dapat diamati dengan mulut (pada waktu digigit,dikunyah dan ditekan) ataupun percobaan dengan jari. 


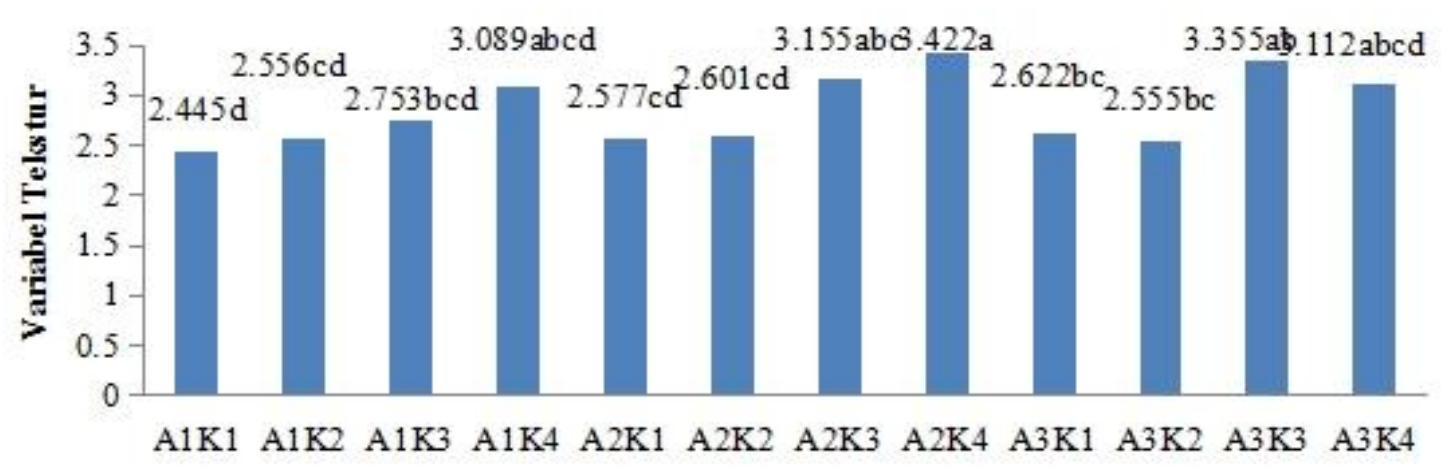

Kombinasi Perlakuan

Keterangan :

1. $A=$ Proporsi tepung ampas kelapa : pati jagung : tepung terigu ( A1: 60\%: 20\%:20\%, A2 : 55\%:15\%:30\%, A3 : 50\%: $10 \%: 40 \%$ )

2. $\mathrm{K}=$ Proporsi dan jenis emulsi $\mathrm{K} 1: 70 \%$ margarin, $\mathrm{K} 2: 80 \%$ margarin, $\mathrm{K} 3: 70 \% \mathrm{VCO}$, $\mathrm{K} 4: 80 \% \mathrm{VCO}$ )

Gambar 4. Nilai rata-rata variable tekstur, pada Kombinasi perlakuan proporsi tepung dengan proporsi dan jenis emulsi.

Adanya pengaruh yang nyata pada kombinasi perlakuan terhadap tekstur cookies. Gambar 4 menunjukan bahwa semakin berkurangnya proporsi tepung ampas kelapa dan meningkatnya proporsi emulsi yang diberikan maka skor tekstur akan semakin tinggi hal ini dikarenakan semakin tingginya tepung terigu dan pati jagung yang digunakan, dan semakin tinggi proporsi emulsi yang diberikan, tepung terigu dan pati jagung memiliki gluten yang tinggi sehingga dapat membentuk tekstur dengan baik.

Tekstur cookies dipengaruhi oleh penggunaan lemak. Hal ini dikarenakan lemak mempunyai kemampuan dalam memerangkap udara sehingga saat proses pencampuran bahanbahan (mixing) udaraakan terperangkap dalam adonan [2]. Tekstur renyah pada cookies ditentukan oleh kandungan gluten dalam bahan. Semakin tinggi gluten dalam bahan maka semakin tinggi pula kemampuannya dalam menyerap air pada permukaan bahan sehingga kadar air bahan semakin tinggi dan menghasilkan tekstur yang renyah [8].

\subsection{Kesukaan}

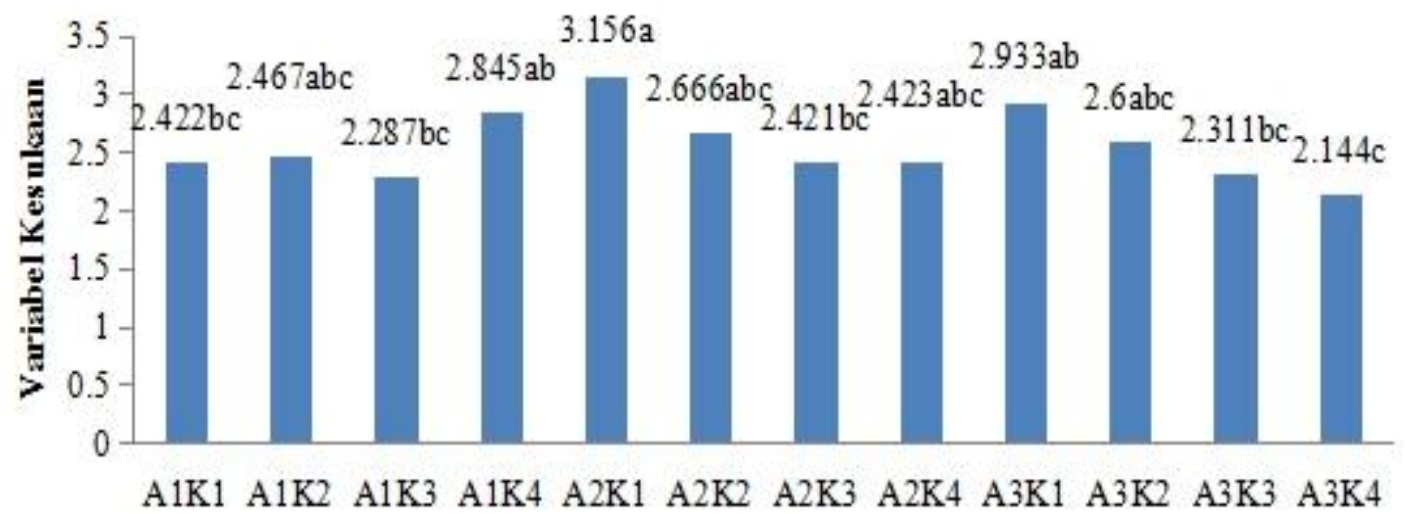

\section{Kombinasi Perlakuan}

Keterangan :

1. $A=$ Proporsi tepung ampas kelapa : pati jagung : tepung terigu ( A1 : 60\%: 20\%:20\% , A2 : 55\%:15\%:30\%, A3 : 50\%: 10\%:40\%) 
2. $\mathrm{K}=$ Proporsi dan jenis emulsi( $\mathrm{K} 1: 70 \%$ margarin, $\mathrm{K} 2: 80 \%$ margarin, $\mathrm{K} 3: 70 \%$ $\mathrm{VCO}, \mathrm{K} 4: 80 \% \mathrm{VCO}$ )

Gambar 5. Nilai rata-rata variable kesukaan, pada kombinasi perlakuan proporsi tepung dengan proporsi dan jenis emulsi.

Gambar 5 adanya kencenderungan penurunan pada kesukaan terhadap cookies tepung ampas kelapa dan adanya perbedaan yang nyata pada setiap kombinasi perlakuan. Hasil tertinggi didapatkan pada perlakuan A2K1 dengan hasil 3.21 dan hasil terendah pada kombinasi perlakuan A3K4 dengan hasil 2.19. Penilaian panelis terhadap kesukaan secara keseluruhan dapat dipengaruhi oleh penilaian terhadap warna, aroma, rasa, dan tekstur cookies secara keseluruhan. Panelis harus menilai beberapa faktor yang bisa mempengaruhi tingkat kesukaannya diantaranya rasa. Rasa lebih banyak melibatkan panca indera lidah [4].

\section{KESIMPULAN}

Kesimpulan dapat dijabarkan sebagai berikut.

1. Semakin menurunnya kandungan tepung ampas kelapa maka akan mempengaruhi sensori cookies yang dihasilkan.

2. Semakin meningkatnya kandungan VCO yang diberikan maka akan meningkatkan aroma dan tekstur namun menurunkan variabel warna, rasa dan kesukaaan terhadap cookies.

3. Kombinasi perlakuan memberikan pengaruh pada variabel sensori cookies dan adanya perbedaan yang nyata pada setiap kombinasi perlakuan pada cookies yang dihasilkan.

\section{SARAN}

Saran yang dapat dikemukakan dalam penelitian antara lain diperlukan penelitian lebih lanjut mengenai penggunaan VCO dari berbagai merek untuk mengetahui pengaruh penambahan VCO terhadap variable warna, rasa dan kesukaan terhadap cookies.

\section{DAFTAR PUSTAKA}

[1] Yulvyanti, M., Widya E., Tarsono dan Alfian, M., 2015, Pemanfaatan Ampas Kelapa Sebagai Bahan Baku Tepung Kelapa dengan Metode Freeze Drying, Jurnal Intergrasi Proses.5(2):101-107.

[2] Nurbaya, S dan Estiasih,T, 2013, Pemanfaatan talas berdaging umbi kuning (Colocasia escuenta L) dalam pembuatan cookies, Jurnal Pangan dan Agroindustri: Malang.

[3] Sujirtha, N., Mahendran, T, 2015, Use of Defatted Coconut Flour as a Source of Protein and Dietary Fibre in Wheat Biscuits, International Journal of Innovative Research in Science, Engineering and Technology, 4(8):7344-52.

[4] Winarno, F, G, 2014, Kelapa Pohon Kehidupan, Jakarta : Gramedia.

[5] Priya,s.r and Lalitha Ramaswarmy, 2016, Organoleptic and nutritional quality of cookies developed using coconut flour, coconut sugar and virgin coconut oil. International journal of current research. 8(04):29701-29707.

[6] Dhankhar, P, 2013, A Study on Development of Coconut Based Gluten Free Cookies, International Journal of Engineering Science Invention. 2(12): 10-19 ISSN (Online): 2319 $-6734$.

[7] Mutiara, T, K, Harijono, Estiasih, T, Sriwah-yuni, E, 2012, Nutrient content of kelor (Moringa oleifera Lamk) leaves powder under different blanching methods, Food and Public Health. 2(6) : 296-300.

[8] Pangaribuan, A, 2013, Substitusi tepung talas belitung pada pembuatan biskuit daun kelor (Moringa oleifera Lamk), Jurnal Program Studi Biologi, Fakultas Teknobiologi, Universitas Atma Jaya: Yogyakarta. 